\begin{tabular}{|c|c|}
\hline Title & $\begin{array}{l}\text { A symmetric Hydrogenation of Polysubstituted A romatic Ketones Catalyzed by the DIPSkewphos/PICA Derivative } \\
\text { Ruthenium(II) Complexes }\end{array}$ \\
\hline Author(s) & $\begin{array}{l}\text { Utsumi, Noriyuki; A rai, Noriyoshi; Kawaguchi, Kei; Katayama, T akeaki; Y asuda, T oshihisa; Murata, Kunihiko; } \\
\text { Ohkuma, T akeshi }\end{array}$ \\
\hline Citation & $\begin{array}{l}\text { ChemCatChem, 10(18), 3955-3959 } \\
\text { https://doi.org/10.1002/cctc.201800848 }\end{array}$ \\
\hline Issue Date & $2018-09-20$ \\
\hline Doc URL & http:/hdl.handle.net/2115/75497 \\
\hline Rights & $\begin{array}{l}\text { This is the peer reviewed version of the following article: ChemCatChem } 10 \text { (18) 3955-3959 2018-09-20, which has } \\
\text { been published in final form at http://doi.org/10.1002/cctc.201800848. This article may be used for non-commercial } \\
\text { purposes in accordance with W iley Terms and Conditions for Self-A rchiving. }\end{array}$ \\
\hline Type & article (author version) \\
\hline File Information & HUSCA P-MS-PolySubstKetone.pdf \\
\hline
\end{tabular}

Instructions for use 


\title{
Asymmetric Hydrogenation of Polysubstituted Aromatic Ketones Catalyzed by the DIPSkewphos/PICA Derivative-Ruthenium(II) Complexes
}

\author{
Noriyuki Utsumi ${ }^{[\mathrm{b}]}$ Noriyoshi Arai, ${ }^{[\mathrm{a}]}$ Kei Kawaguchi, ${ }^{[\mathrm{a}]}$ Takeaki Katayama, ${ }^{[\mathrm{b}]}$ Toshihisa Yasuda ${ }^{[\mathrm{b}]}$ \\ Kunihiko Murata, ${ }^{[b]}$ and Takeshi Ohkuma* ${ }^{\star[a]}$
}

\begin{abstract}
The DIPSkewphos/PICA derivative-Ru(II) complexes catalyzed asymmetric hydrogenation of significantly sterically hindered 2', 3', 4', 5',6'-pentamethylacetophenone, which was not reduced with $\mathrm{NaBH}_{4}$ at $25^{\circ} \mathrm{C}$, with a substrate-to-catalyst molar ratio (S/C) of 2000 under $50 \mathrm{~atm}$ of $\mathrm{H}_{2}$ in a base-containing 2-propanol to afford the alcohol in $99 \%$ ee quantitatively. A series of polysubstituted aromatic ketones was smoothly reacted with an S/C of $300-10,000$ under $10-50$ atm of $\mathrm{H}_{2}$, yielding the alcoholic products in up to $99 \%$ ee. The catalyst system achieved an industrial-scale $(50 \mathrm{~kg})$ hydrogenation of 2',6'-dichloro-3'fluoroacetophenone, affording the alcohol in $96 \%$ isolated yield and in $98 \%$ ee. The obtained alcoholic product is known as a key intermediate for the synthesis of the medicine crizotinib.
\end{abstract}

Asymmetric hydrogenation of ketones affording opticallyenriched secondary alcohols has remarkably contributed to fine stereoselective synthesis of a wide variety of biologically active compounds, such as medicines, agrochemicals, and perfumes. ${ }^{[1]}$ The high atom-efficiency and operational simplicity allow the reaction to be conducted on an industrial scale. ${ }^{[2]}$ Acetophenone a simple aromatic ketone, has frequently been used as a standard substrate to evaluate the efficiency of hydrogenation catalysts. However, the reactivity of the carbonyl group is drastically changed by introducing substituents on the phenyl ring. For example, acetophenone itself is readily reduced with $\mathrm{NaBH}_{4}$ (1.5 equiv) in methanol to give 1-phenylethanol quantitatively (Scheme 1). In contrast, in our hands, the

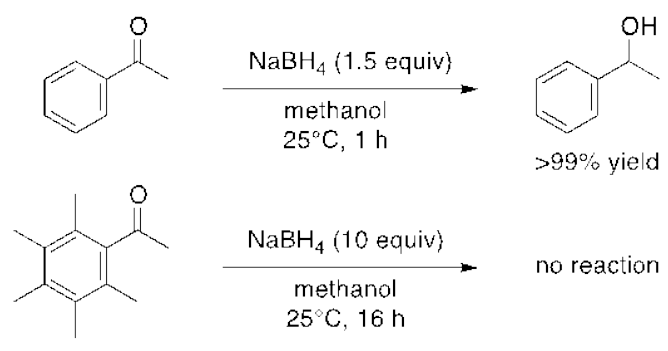

Scheme 1. Reduction of acetophenones with $\mathrm{NaBH}_{4}$

[a] Prof. Dr. N. Arai, K. Kawaguchi, Prof. Dr. T. Ohkuma Division of Applied Chemistry and Frontier Chemistry Center Faculty of Engineering, Hokkaido University

Sapporo, Hokkaido 060-8628 (Japan)

E-mail: ohkuma@eng.hokudai.ac.jp

[b] N. Utsumi, T. Katayama, T. Yasuda, Dr. K. Murata Central Research Laboratory, Technology and Development Division, Kanto Chemical Co., Inc., Soka, Saitama 340-0003 (Japan)

Supporting information for this article is given via a link at the end of the document.

reduction of $2^{\prime}, 3^{\prime}, 4^{\prime}, 5^{\prime}, 6^{\prime}$-pentamethylacetophenone resulted in no reaction with ten equivalents of $\mathrm{NaBH}_{4}$ in $16 \mathrm{~h}$. Development of efficient catalysts to hydrogenate such sterically hindered aromatic ketones is a challenging scientific subject. Moreover, several medicinal compounds synthesized from optically active polysubstituted 1-arylethanols have been developed in recent years. $^{[3]}$ Thus, we began an investigation of the asymmetric hydrogenation of polysubstituted aromatic ketones by our original Ru(II) catalysts. ${ }^{[4]}$ The hardly reducible ortho-substituted ketones were the primary targets.

Table 1. Asymmetric hydrogenation of pentasubstituted acetophenones 1 catalyzed by chiral Ru complexes. ${ }^{[a]}$

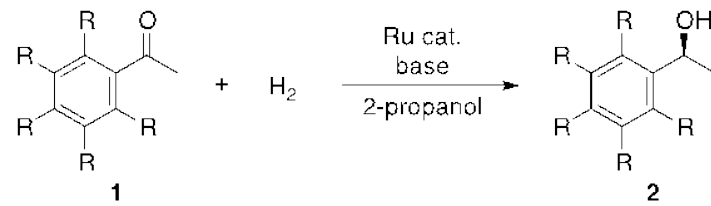

a: $\mathrm{R}=\mathrm{CH}_{3} ; \mathbf{b}: \mathrm{R}=\mathrm{F}$

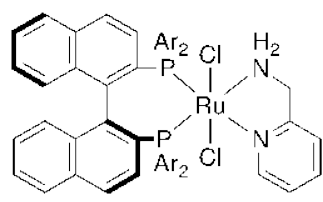

(S) $-3: \mathrm{Ar}=4-\mathrm{MeC}_{6} \mathrm{H}_{4}$

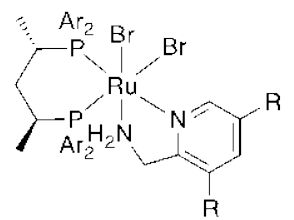

(S)-4a: $\mathrm{Ar}=3,5-\mathrm{Me}_{2} \mathrm{C}_{6} \mathrm{H}_{3}, \mathrm{R}=\mathrm{H}$

(S) $-4 \mathbf{b}: \mathrm{Ar}=3,5-\mathrm{Me}_{2} \mathrm{C}_{6} \mathrm{H}_{3}, \mathrm{R}=\mathrm{Me}$

(S)-4c: $\mathrm{Ar}=3,5-\mathrm{Pr}_{2} \mathrm{C}_{6} \mathrm{H}_{3}, \mathrm{R}=\mathrm{Me}$
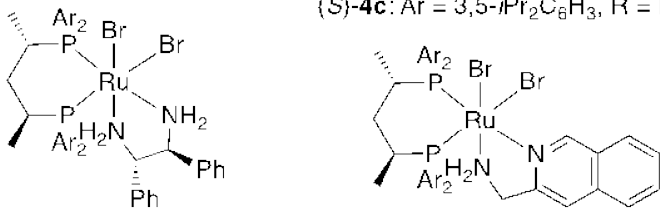

(S) $6:$ : A

$\left(S_{0} . S_{N}\right)-5:$ Ar $=$

\begin{tabular}{|c|c|c|c|c|c|c|c|}
\hline Entry & 1 & Ru cat. & $S / C^{[b]}$ & Base & $\begin{array}{l}\mathrm{H}_{2} \\
\text { [atm] }\end{array}$ & $\begin{array}{l}\text { Yield } \\
{[\%]^{[c]}}\end{array}$ & $\begin{array}{l}e e \\
{[\%]^{[\mathrm{d}]}}\end{array}$ \\
\hline 1 & $1 a$ & $(S)-3$ & 200 & $t \mathrm{BuOK}$ & 10 & $<1$ & $\mathrm{Nd}^{[\mathrm{e}]}$ \\
\hline 2 & $1 a$ & (S)-4a & 200 & tBuOK & 10 & 83 & 88 \\
\hline 3 & $1 a$ & (S)-4b & 200 & $t \mathrm{BuOK}$ & 10 & 94 & 93 \\
\hline 4 & $1 a$ & $\begin{array}{l}\left(S_{P}, S_{N}\right)- \\
\mathbf{5}\end{array}$ & 200 & tBuOK & 10 & $<1$ & $\mathrm{Nd}^{[\mathrm{e}]}$ \\
\hline 5 & $1 a$ & (S)-4c & 200 & $t \mathrm{BuOK}$ & 10 & 96 & 94 \\
\hline 6 & $1 a$ & $(S)-6$ & 200 & tBuOK & 10 & 98 & 99 \\
\hline 7 & $1 a$ & $(S)-6$ & 200 & $t \mathrm{BuONa}$ & 10 & 96 & 99 \\
\hline 8 & $1 a$ & $(S)-6$ & 500 & $t \mathrm{BuONa}$ & 10 & 95 & 99 \\
\hline 9 & $1 a$ & $(S)-6$ & 2000 & tBuONa & 50 & $>99(96)^{[f]}$ & 99 \\
\hline 10 & $1 b$ & $(S)-6$ & 300 & tBuOK & 10 & 20 & 96 \\
\hline 11 & $1 b$ & (S)-6 & 300 & $t \mathrm{BuOK}$ & 50 & $92(85)^{[f]}$ & 96 \\
\hline
\end{tabular}

[a] Unless otherwise stated, the reactions were carried out under $\mathrm{H}_{2}$ at $40^{\circ} \mathrm{C}$ for $21 \mathrm{~h}$ using ketone $1(1.0 \mathrm{M})$ in 2-propanol containing a Ru complex and a base $(30 \mathrm{mM})$. [b] Substrate-to-catalyst molar ratio. [c] Determined by GC 
or ${ }^{1} \mathrm{H}$ NMR analysis. [d] Determined by chiral GC or HPLC analysis. [e] Not determined. [f] Isolated yields of $\mathbf{2}$ are indicated in parentheses.

We selected 2',3',4',5',6'-pentamethylacetophenone (1a) as a standard substrate to evaluate the efficiency of a series of catalysts. The hydrogenation of 1 a was conducted with a $\mathrm{Ru}(\mathrm{II})$ complex at a substrate-to-catalyst molar ratio (S/C) of 200 in a tBuOK-containing 2-propanol $\left([\mathbf{1} \mathbf{a}]_{0}=1.0 \mathrm{M}\right.$, $\left.[t \mathrm{BuOK}]=30 \mathrm{mM}\right)$ under $10 \mathrm{~atm}$ of $\mathrm{H}_{2}$ at $40^{\circ} \mathrm{C}$ in $21 \mathrm{~h}$ (Table 1). Only trace amounts of the alcoholic product $2 \mathrm{a}$ were observed in the reaction with $\mathrm{RuCl}_{2}[(S)$-tolbinap](pica) ((S)-3), which showed high catalytic activity in the hydrogenation of the sterically hindered tert-alkyl ketones and acylsilanes (Entry 1). ${ }^{[5,6]}$ The catalytic activity was dramatically increased by using the $(S, S)$ Xylskewphos/PICA-Ru(II) complex (S)-4a to afford (S)-2a in $83 \%$ yield and $88 \%$ ee (Entry 2$)^{[6-9]}$ Introduction of methyl groups at the 3 and 5 positions on the PICA-pyridine ring (3,5$\left.\mathrm{Me}_{2} \mathrm{PICA}\right)^{[6]}$ improved both the catalytic activity and enantioselectivity (Entry 3). The (S,S)-XylSkewphos/(S,S)DPEN-Ru(II) complex $\left(\left(S_{P}, S_{N}\right)-5\right)$ showed marginal catalytic activity, indicating the importance of the PICA structure for this reaction (Entry 4). ${ }^{[6,10]}$ The more sterically demanding diphosphine $(S, S)$-DIPSkewphos matched with 3,5-Me ${ }_{2} \mathrm{PICA}$ $((S)-4 c)$ to yield (S)-2a in 94\% ee (Entry 5). ${ }^{[6]}$ The Ru(II) complex combined with DIPSkewphos and 3aminomethylisoquinoline (3-AMIQ) ((S)-6) exhibited even higher enantioselectivity under the regular conditions to afford (S)-2a in $99 \%$ ee (Entry 6). ${ }^{[6,11,12]}$ The reaction using $t$ BuONa instead of tBuOK as a base gave a comparable result (Entry 7). The high catalytic activity of the (S)-6/tBuONa system enabled the hydrogenation with an S/C of 500 under 10 atm of $\mathrm{H}_{2}$ and an $\mathrm{S} / \mathrm{C}$ of 2000 under $50 \mathrm{~atm}$ of $\mathrm{H}_{2}$ with maintenance of the excellent enantioselectivity (Entries 8 and 9). The reaction of 2', 3', 4', 5',6'-pentafluoroacetophenone (1b), another pentasubstituted acetophenone, with an S/C of 300 under $10 \mathrm{~atm}$ of $\mathrm{H}_{2}$ was slow, but the desired alcohol $\mathbf{2 b}$ in $96 \%$ ee was obtained with a high yield of $92 \%$ under 50 atm of $\mathrm{H}_{2}$ (Entries 10 and 11). ${ }^{[13]}$

We next applied the catalyst systems to the asymmetric hydrogenation of a range of polysubstituted aromatic ketones 7 in 2-propanol or ethanol (Table 2). In most cases the DIPSkewphos/3-AMIQ-Ru(II) complex 6 achieved the best enantioselectivity. The reaction of 2', 4',6'trimethylacetophenone (7a) catalyzed by $4 \mathbf{c}$ or $\mathbf{6}$ with $t \mathrm{BuOK}$ or $t B u O N a$ was completed even at an S/C of 2000 under $10 \mathrm{~atm}$ of $\mathrm{H}_{2}$ in $21 \mathrm{~h}$ to give the alcohol 8a in 98\% ee (Entries 1-3). ${ }^{[14]}$ The marked difference in the reaction rate between the ketones 1a and $7 \mathrm{a}$ suggests that the meta-substituents on the phenyl ring influence the catalytic activity. 2',6'-Dichloro-3'fluoroacetophenone (7b) was quantitatively converted with $\mathbf{4 b}$, $\mathbf{4 c}$, or $\mathbf{6}$ to the alcohol $\mathbf{8 b}$ in $98-99 \%$ ee (Entries 4-6). ${ }^{[15]}$ The reaction of 2',4',5'-trimethoxyacetophenone (7c), an electron-rich ketone, quantitatively yielded the alcohol $\mathbf{8 c}$ in $99 \%$ ee under the regular conditions (Entries 7-9). 2',6'-Dichloro- and dimethoxyacetophenones, $\mathbf{7 d}$ and $\mathbf{7 e}$, were also appropriate substrates for this reaction, resulting in the alcohols $\mathbf{8 d}$ and $\mathbf{8 e}$ in up to $99 \%$ ee quantitatively regardless of the electronic properties of the substituents (Entries 10-14). The more sterically hindered 2',6'-diethoxyacetophenone (7f) was a difficult substrate to hydrogenate with high reactivity and enantioselectivity with $\mathbf{4 b}$ and $\mathbf{4 c}$ (Entries 15 and 16).

Table 2. Asymmetric hydrogenation of polysubstituted aromatic ketones 7. ${ }^{[\mathrm{a}]}$

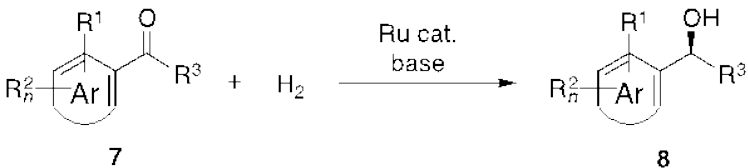
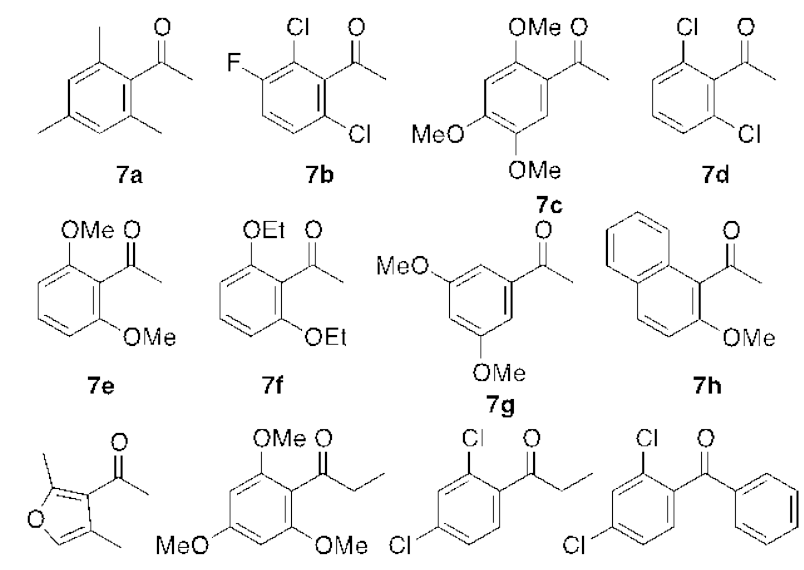

\begin{tabular}{|c|c|c|c|c|c|c|c|}
\hline & $7 i$ & & $7 \mathrm{~J}$ & & $7 \mathrm{k}$ & 71 & \\
\hline Entry & 7 & $\begin{array}{l}\mathrm{Ru} \\
\text { cat. }\end{array}$ & $S / C^{[b]}$ & Base & Solvent & Yield [\%] ${ }^{[c]}$ & $\begin{array}{l}e e \\
{[\%]^{[d]}}\end{array}$ \\
\hline 1 & $7 a$ & $(S)-4 c$ & 2000 & tBuOK & iPrOH & $98(97)$ & 98 \\
\hline 2 & $7 a$ & $(S)-6$ & 2000 & tBuOK & iPrOH & $>99(99)$ & 98 \\
\hline 3 & $7 a$ & $(S)-6$ & 2000 & $t \mathrm{BuONa}$ & iPrOH & $>99(97)$ & 98 \\
\hline 4 & $7 b$ & $(S)-\mathbf{4 b}$ & 1000 & $t$ BuOK & iPrOH & $>99$ & 98 \\
\hline 5 & $7 b$ & (S)-4c & 1000 & $t \mathrm{BuOK}$ & iPrOH & $>99$ & 98 \\
\hline 6 & $7 b$ & $(S)-6$ & 1000 & tBuOK & iPrOH & $>99(93)$ & 99 \\
\hline 7 & 7c & $(S)-4 c$ & 2000 & tBuOK & EtOH & $>99(98)$ & 99 \\
\hline 8 & 7c & $(S)-6$ & 2000 & tBuOK & $\mathrm{EtOH}$ & $>99(99)$ & 99 \\
\hline 9 & 7c & $(S)-6$ & 2000 & tBuONa & EtOH & $>99(98)$ & 99 \\
\hline 10 & $7 d$ & (S)-4c & 2000 & tBuOK & iPrOH & 99(95) & 99 \\
\hline 11 & $7 d$ & $(S)-6$ & 2000 & tBuOK & iPrOH & $>99(99)$ & 99 \\
\hline 12 & $7 e$ & $(S)-4 c$ & 2000 & tBuOK & iPrOH & $>99(95)$ & 96 \\
\hline 13 & $7 e$ & $(S)-6$ & 2000 & tBuOK & $i \mathrm{PrOH}$ & $>99(99)$ & 98 \\
\hline 14 & $7 e$ & $(S)-6$ & 2000 & tBuONa & iPrOH & $>99(99)$ & 98 \\
\hline 15 & $7 f$ & $(S)-\mathbf{4 b}$ & 500 & tBuOK & iPrOH & 91 & 93 \\
\hline 16 & $7 f$ & (S)-4c & 500 & tBuOK & $i \mathrm{PrOH}$ & 98 & 92 \\
\hline 17 & $7 f$ & $(S)-6$ & 500 & tBuOK & $i \mathrm{PrOH}$ & $>99(97)^{[\mathrm{e}]}$ & 95 \\
\hline 18 & $7 g$ & (S)-4c & 2000 & tBuOK & EtOH & $>99^{[f, g]}$ & 97 \\
\hline 19 & $7 g$ & $(S)-6$ & 2000 & tBuOK & $\mathrm{EtOH}$ & $>99(100)^{[f, g]}$ & 98 \\
\hline 20 & $7 \mathrm{~h}$ & $(S)-4 c$ & 1000 & tBuOK & iPrOH & $>99(97)$ & 99 \\
\hline 21 & $7 \mathrm{~h}$ & $(S)-6$ & 1000 & tBuOK & iPrOH & $>99(99)$ & 99 \\
\hline 22 & $7 i$ & $(S)-4 c$ & 1000 & tBuOK & iPrOH & 91 & 97 \\
\hline 23 & $7 \mathbf{i}$ & $(S)-6$ & 1000 & tBuOK & iPrOH & $99(93)^{[\mathrm{h}]}$ & 95 \\
\hline 24 & $7 \mathbf{j}$ & $(S)-4 c$ & 1000 & tBuOK & iPrOH & $98(94)^{[i]}$ & 99 \\
\hline 25 & $7 \mathbf{j}$ & $(S)-6$ & 1000 & tBuOK & iPrOH & $>99(97)^{[\mathrm{e}]}$ & 99 \\
\hline 26 & $7 \mathrm{k}$ & (S)-4c & 1000 & $t \mathrm{BuOK}$ & iPrOH & 99(99) & 99 \\
\hline 27 & $7 k$ & $(S)-6$ & 1000 & tBuOK & iPrOH & $93(92)$ & 99 \\
\hline 28 & 71 & $(S)-6$ & 1000 & tBuOK & $\mathrm{iPrOH}$ & $96(93)^{[g]}$ & 37 \\
\hline
\end{tabular}

[a] Unless otherwise stated, the reactions were carried out under 10 atm of $\mathrm{H}_{2}$ at $40^{\circ} \mathrm{C}$ for $21-24 \mathrm{~h}$ using ketone $7(0.5-2.0 \mathrm{M})$ in solvent containing a Ru complex and a base (20-30 mM). [b] Substrate-to-catalyst molar ratio. [c] Determined by GC or ${ }^{1} \mathrm{H}$ NMR analysis. Isolated yields of $\mathbf{8}$ are indicated in 
parentheses. [d] Determined by chiral GC or HPLC analysis. [e] Reaction for $36 \mathrm{~h}$. [f] Reaction at $30-33^{\circ} \mathrm{C}$ [g] Reaction for $16 \mathrm{~h}$. [h] Reaction for 8 h. [i] Reaction for $30 \mathrm{~h}$.

Fortunately, the desired alcohol 8 f was quantitatively obtained with a high level of enantiomeric purity of $95 \%$ in the presence of 6 with an S/C of 500 under 10 atm of $\mathrm{H}_{2}$ in $36 \mathrm{~h}$ (Entry 17). Less hindered 3',5'-dimethoxyacetophenone (7g) was smoothly hydrogenated with an S/C of 2000 to afford $\mathbf{8 g}$ in up to $98 \%$ ee (Entries 18 and 19). The reaction of 2'-methoxy-1'acetonaphthone $(\mathbf{7 h})$ with a fused ring structure in the presence of $4 \mathrm{c}$ or $\mathbf{6}$ at an S/C of 1000 quantitatively afforded the $8 \mathrm{~h}$ in 99\% ee (Entries 20 and 21). 3-Acetyl-2,4-dimethylfuran (7i), a disubstituted heteroaromatic ketone, was also hydrogenated with 95\%-97\% enantioselectivity (Entries 22 and 23). The enantiomeric purity of the alcohol $\mathbf{8 i}$ was gradually reduced with a prolonged reaction time in the hydrogenation using $4 c$ (Entry 22). In contrast, the reaction in the presence of $\mathbf{6}$ was completed in $8 \mathrm{~h}$ with the maintenance of high enantiomeric purity (Entry 23). The polysubstituted propiophenone derivatives $7 \mathbf{j}$ and $\mathbf{7 k}$, were also smoothly converted with $\mathbf{4 c}$ or $\mathbf{6}$ at an S/C of 1000 to the corresponding alcohols, $\mathbf{8 j}$ and $\mathbf{8 k}$, both in $99 \%$ ee (Entries 24-27). The hydrogenation of 2,4dichlorobenzophenone (7I) gave the benzhydrol $8 \mathbf{l}$ with modest enantioselectivity (Entry 28). ${ }^{[16]}$

Finally, we applied the catalyst system to an industrial-scale hydrogenation of $\mathbf{7 b}$ (Scheme 2 ). The reaction was conducted in a 200-L stainless steel autoclave by using $50.0 \mathrm{~kg}$ of $7 \mathbf{b}$ and (S)-4b $(23.0 \mathrm{~g}, \mathrm{~S} / \mathrm{C}=10,000)$ in $85 \mathrm{~L}$ of $t$ BuOK $(542 \mathrm{~g})$ containing 2-propanol $\left([7 \mathrm{~b}]_{0}=2.0 \mathrm{M}\right.$, $\left.[\mathrm{tBuOK}]=40 \mathrm{mM}\right)$ under $10 \mathrm{~atm}$ of $\mathrm{H}_{2}$ at $40^{\circ} \mathrm{C}$ in $25 \mathrm{~h}$ to afford the alcohol (S)-8b $(48.6 \mathrm{~kg}$ $96 \%$ yield) in $98 \%$ ee (see the Supporting Information in detail). The alcohol (S)-8b is a key intermediate in the synthesis of crizotinib, a medicine for the treatment of locally advanced or metastatic non-small cell lung cancer. ${ }^{[3 c, 17]}$

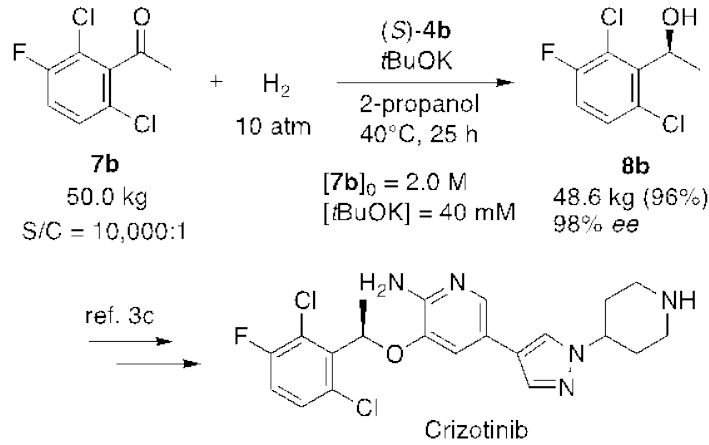

Scheme 2. Practical-scale hydrogenation of $7 \mathbf{b}$.

The cis- $\mathrm{RuH}_{2}[(S)$-dipskewphos](3-amiq) ((S)-9) is proposed to be the active species derived from (S)-6/tBuONa catalytic system based on the related previous studies. ${ }^{[4,8-10,18]}$ Scheme 3 illustrates the molecular models of (S)-9 and plausible diastereomeric transition states (TSs) $\mathbf{T S}_{\boldsymbol{R e}}$ and $\mathbf{T S}_{\boldsymbol{S i}}$ in the hydrogenation of the pentamethylphenyl ketone 1a. The more nucleophilic $\mathrm{H}_{\mathrm{A}}$ connecting to $\mathrm{Ru}$ at the trans position to the $\mathrm{PAr}_{2}$ group reacts as a hydride. The hydrogenation of $\mathbf{1 a}$ proceed through the six-membered metal-ligand cooperated TS $\mathbf{T S}_{R e}$ or $\mathbf{T S}_{S i}$ in which the $\mathrm{C}^{\delta_{+}}=\mathrm{O}^{\delta_{-}}$dipole of ketone interacts

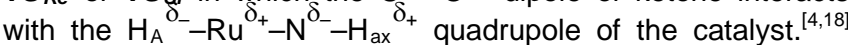
The $\mathbf{T S}_{S i}$ suffers significant steric repulsion between the pentamethylphenyl ring of 1a and the diisopropylphenyl group of the catalyst. In contrast, the $\mathbf{T} \mathbf{S}_{R e}$ has no such repulsion because the hindered pentamethylphenyl ring is placed above the flat isoquinoline group of the catalyst. Therefore, the $\mathbf{T S}_{R e}$ is much favored over $\mathbf{T} \mathbf{S}_{\boldsymbol{s i}}$, and it affords (S)-2a. Low activity of the catalyst derived from XylSkewphos/DPEN-Ru complex $\mathbf{5}$ may be due to insufficient reaction area to accept the hindered ketone $1 \mathbf{a}$ around the catalytic species.

In conclusion, we here reported asymmetric hydrogenation of polysubstituted aromatic ketones with the DIPSkewphos/PICA derivative-Ru(II) catalysts in a base (tBuOK or tBuONa)containing 2-propanol or ethanol. Significantly sterically hindered 2', 3', 4', 5', 6'-pentamethylacetophenone, which was not reduced with $\mathrm{NaBH}_{4}$ at $25^{\circ} \mathrm{C}$, was quantitatively hydrogenated with an S/C of 2000 under 50 atm of $\mathrm{H}_{2}$ to afford the alcohol in 99\% ee. Both Skewphos and PICA ligand-structures were crucial to achieve high catalytic activity and enantioselectivity. A range of polysubstituted aromatic ketones was smoothly hydrogenated with an S/C of 300-10,000 under 10-50 atm of $\mathrm{H}_{2}$ to give the chiral alcohols in $99 \%$ ee in the best cases. The high catalyst efficiency achieved an industrial-scale $(50 \mathrm{~kg})$ hydrogenation of 2',6'-dichloro-3'-fluoroacetophenone to afford the alcoholic product in $96 \%$ isolated yield and $98 \%$ ee as a key intermediate for the synthesis of the medicine crizotinib.

\section{Experimental Section}

Asymmetric hydrogenation of 1a with Ru complex (S)-6 at an S/C of 2000 under $50 \mathrm{~atm}$ of $\mathrm{H}_{2}$ (Table 1, Entry 9)

The ruthenium complex (S)-6 (1.0 mg, $0.84 \mu \mathrm{mol})$, tBuONa $(4.9 \mathrm{mg}, 51$ $\mu \mathrm{mol})$, ketone $1 \mathrm{a}(318.9 \mathrm{mg}, 1.68 \mathrm{mmol})$, and a Teflon-coated stirring bar were placed in a $30 \mathrm{~mL}$ glass test tube inside a stainless autoclave that had been filled with argon. The reaction vessel was then evacuated and refilled with argon. 2-Propanol $(1.7 \mathrm{~mL})$ that had been degassed by three freeze-thaw cycles was transferred into the autoclave through a Teflon cannula. Hydrogen was initially introduced into the autoclave at a pressure of $20 \mathrm{~atm}$ before being reduced to $5 \mathrm{~atm}$. This procedure was repeated five times. The autoclave was then pressurized with $\mathrm{H}_{2}$ gas (50 atm), and the solution was stirred vigorously at $40^{\circ} \mathrm{C}$ for $21 \mathrm{~h}$. After careful release of the hydrogen, the solution was concentrated under reduced pressure. Purification by a preparative TLC (developed with hexane/ethyl acetate $=2: 1)$ gave (S)-1-(2,3,4,5,6pentamethylphenyl)ethanol ((S)-2a) (309.5 mg, $1.61 \mathrm{mmol}, 96 \%, 99 \%$ ee).

\section{Acknowledgements}

This work was supported by a Grant-in-Aid from the Japan Society for the Promotion of Science (JSPS) (No. 15H03802) and the MEXT (Japan) program "Strategic Molecular and Materials Chemistry through Innovative Coupling Reactions" of Hokkaido University. 
Keywords: alcohol • asymmetric catalysis $\bullet$ hydrogenation •

ketone $\bullet$ ruthenium

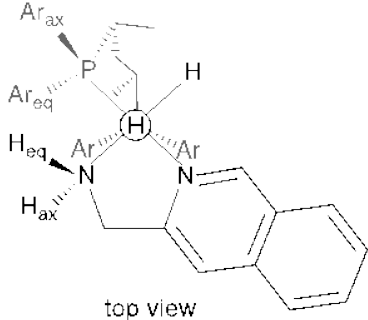

top view

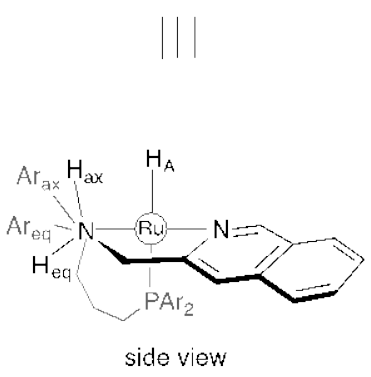

(S) -9
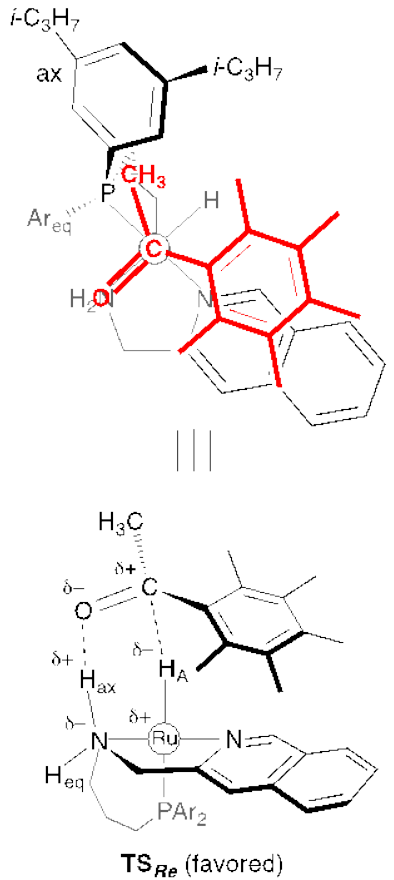

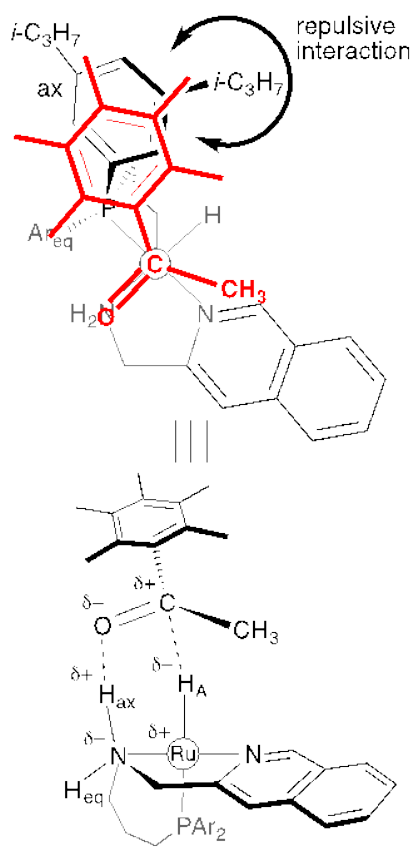

$\mathrm{TS}_{\mathrm{Si}}$ (disfavored)

Scheme 3. Structure of $\mathrm{RuH}_{2}$ complex (S)-9 derived from (S)-6 and diastereomeric TS models in the hydrogenation of $\mathbf{1 a}$. The structures are simplified for clarity. $\mathrm{Ar}=3,5-\mathrm{Pr}_{2} \mathrm{C}_{6} \mathrm{H}_{3}$

[1] Selected reviews: a) T. Ohkuma, R. Noyori in The Handbook of Homogeneous Hydrogenation, Vol. 3 (Eds.: J. G. de Vries, C. J. Elsevier), Wiley-VCH, Weinheim, 2007, pp. 1105-1163; b) N. Arai, T. Ohkuma in Science of Synthesis: Stereoselective Synthesis 2; Stereoselective Reactions of Carbonyl and Imino Groups (Ed.: G. A Molander), Thieme, Stuttgart, 2010, pp. 9-57; c) T. Ohkuma and N. Arai in Comprehensive Chirality, Vol. 5 (Eds.: E. M. Carreira, H. Yamamoto, K. Maruoka), Elsevier, Amsterdam, 2012, pp. 270-300; d) J.-H. Xie, D.-H. Bao, Q.-L. Zhou, Synthesis 2015, 47, 460-471.

[2] a) Asymmetric Catalysis on Industrial Scale (Eds.: H. U. Blaser, E. Schmidt), Wiley-VCH, Weinheim, 2003; b) N. Arai, T. Ohkuma, Chem. Rec. 2012, 12, 284-289.

[3] For example, see: a) M. M. Zhao, J. M. McNamara, G.-J. Ho, K. M. Emerson, Z. J. Song, D. M. Tschaen, K. M. J. Brands, U. Dolling, E. J. J. Grabowski, P. J. Reider, I. F. Cottrell, M. S. Ashwood, B. C. Bishop, J. Org. Chem. 2002, 67, 6743-6747; b) H. Takemoto, M. Takayama, T. Shiota, Jpn. Kokai Tokkyo Koho P4145655, 2008; c) P. D. de Koning, D. McAndrew, R. Moore, I. B. Moses, D. C. Boyles, K. Kissick, C. L. Stanchina, T. Cuthbertson, A. Kamatani, L. Rahman, R. Rodriguez, A. Urbina, A. Sandoval (née Accacia), P. R. Rose, Org. Process Res. Dev. 2011, 15, 1018-1026; d) M. Takayama, N. Kurose, Jpn. Kokai Tokkyo Koho P5164181, 2013; e) M. R. Leleti, Y. Li, V. R. Mali, J. Powers, J. Yang, PCT Int. WO 2013/082429 A1, 2013.

[4] Reviews: a) T. Ohkuma, Proc. Jpn. Acad., Ser. B 2010, 86, 202-219; b) T. Ohkuma, N. Arai, Chem. Rec. 2016, 16, 2801-2819.

[5] a) T. Ohkuma, C. A. Sandoval, R. Srinivasan, Q. Lin, Y. Wei, K. Muñiz, R. Noyori, J. Am. Chem. Soc. 2005, 127, 8288-8289; b) N. Arai, K. Suzuki, S. Sugizaki, H. Sorimachi, T. Ohkuma, Angew. Chem. 2008, 120, 1794-1797; Angew. Chem. Int. Ed. 2008, 47, 1770-1773.

[6] TolBINAP $=2,2$ '-bis(di-4-tolylphosphino)-1,1'-binaphthyl. PICA $=\alpha$ picolylamine. XylSkewphos $=2,4$-bis(di-3,5-xylylphosphino)pentane. 3,5-Me ${ }_{2}$ PICA $=2$-aminomethyl-3,5-dimethylpyridine. $\quad$ DPEN $=1,2$ - diphenylethylenediamine. $\quad$ DIPSkewphos $=2,4$-di(bis(3,5diisopropylphenyl)phosphino)pentane.

[7] T. Katayama, K. Tsutsumi, K. Murata, T. Ohkuma, N. Arai, Jpn. Kokai Tokkyo Koho P2015-24975, 2015.

[8] The Ru(II) complex (S)-4a was utilized in the industrial synthesis of $(R)$ 3-quinuclidinol, which is a key building block of the medicine solifenacin. See: K. Tsutsumi, T. Katayama, N. Utsumi, K. Murata, N. Arai, N. Kurono, T. Ohkuma, Org. Process Res. Dev. 2009, 13, 625-628.

[9] For the transfer hydrogenation of ketones using $\mathrm{RuCl}_{2}$ (diphosphine)(pica), see: W. Baratta, E. Herdtweck, K. Siega, M. Toniutti, P. Rigo, Organometallics 2005, 24, 1660-1669.

[10] For enantioselective hydrogenation of $\mathrm{N}$-aryl imines with the $\mathrm{Ru}(\mathrm{II})$ complex $\left(S_{P}, S_{N}\right)-5$, see: N. Arai, N. Utsumi, Y. Matsumoto, K. Murata, K. Tsutsumi, T. Ohkuma, Adv. Synth. Catal. 2012, 354, 2089-2095.

[11] For asymmetric hydrogenation of keto esters into the hydroxyl esters or the diols with the Ru(II) complex (S)-6, see: N. Arai, T. Namba, K. Kawaguchi, Y. Matsumoto, T. Ohkuma, Angew. Chem. 2018, 130, 1400-1403; Angew. Chem. Int. Ed. 2018, 57, 1386-1389.

[12] Asymmetric reduction of $1 \mathrm{a}$ with 4 equivalents of poly(methylhydroxysilane) in THF at $65^{\circ} \mathrm{C}$ for $24 \mathrm{~h}$ catalyzed by a chiral Fe complex with an S/C of 20 gave $2 a$ in $45 \%$ yield and $99 \%$ ee. See: N. S. Shaikh, S. Enthaler, K. Junge, M. Beller, Angew. Chem. 2008, 120, 2531-2535; Angew. Chem. Int. Ed. 2008, 47, 2497-2501.

[13] Transfer hydrogenation of $\mathbf{1 b}$ with the chiral Re catalyst at an S/C of 100 in 2-propanol at $80^{\circ} \mathrm{C}$ for $20 \mathrm{~h}$ afforded $2 \mathrm{~b}$ in $46 \%$ ee quantitatively. See: E. Mejía, R. Aardoom, A. Togni, Eur. J. Inorg. Chem. 2012, 50215032

[14] Hydrogenation of $7 \mathrm{a}$ with the chiral bis(oxazolinyl)phenyl-Ru(II) dimer including a $\mathrm{ZnCl}_{4}$ bridge at an S/C of 100 under 30 atm of $\mathrm{H}_{2}$ in $24 \mathrm{~h}$ gave $\mathbf{8 a}$ in $98 \%$ yield and $95 \%$ ee. See: a) J. Ito, S. Ujiie, H. Nishiyama, Organometallics 2009, 28, 630-638; b) J. Ito, T. Teshima, H. Nishiyama, Chem. Commun. 2012, 48, 1105-1107. 
[15] Hydrogenation of $\mathbf{7 b}$ catalyzed by an $\operatorname{Ir}$ (III) complex with chiral tridentate ligand at an S/C of 100,000 under 30 atm of $\mathrm{H}_{2}$ in $24 \mathrm{~h}$ quantitatively gave $\mathbf{8 b}$ in $99.5 \%$ ee. See: J.-Q. Qian, P.-C. Yan, D.-Q. Che, Q.-L. Zhou, Y.-Q. Li, Tetrahedron Lett. 2014, 55, 1528-1531.

[16] For asymmetric hydrogenation of unsymmetrical diaryl ketones with the diphosphine/diamine-Ru(II) catalysts, see: T. Ohkuma, M. Koizumi, H. Ikehira, T. Yokozawa, R. Noyori, Org. Lett. 2000, 2, 659-662.

[17] J. J. Cui, M. Tran-Dubé, H. Shen, M. Nambu, P.-P. Kung, M. Pairish, L. Jia, J. Meng, L. Funk, I. Botrous, M. McTigue, N. Grodsky, K. Ryan, E.
Padrique, G. Alton, S. Timofeevski, S. Yamazaki, Q. Li, H. Zou, J. Christensen, B. Mroczkowski, S. Bender, R. S. Kania, M. P. Edwards, J. Med. Chem. 2011, 54, 6342-6363.

[18] a) K. Abdur-Rashid, S. E. Clapham, A. Hadzovic, J. N. Harvey, A. J. Lough, R. H. Morris, J. Am. Chem. Soc. 2002, 124, 15104-15118; b) C. A. Sandoval, T. Ohkuma, K. Muñiz, R. Noyori, J. Am. Chem. Soc. 2003, 125, 13490-13503; c) R. J. Hamilton, S. H. Bergens, J. Am. Chem. Soc. 2006, 128, 13700-13701. 
Entry for the Table of Contents (Please choose one layout)Layout 1:

\section{COMMUNICATION}

Asymmetric hydrogenation of polysubstituted aromatic ketones was achieved by using the DIPSkewphos/PICA derivative-Ru(II) catalysts. Significantly sterically hindered 2',3',4',5',6'-pentamethylacetophenone was quantitatively converted to the alcohol in $99 \%$ ee. Industrial-scale $(50 \mathrm{~kg})$ reaction of 2',6'-dichloro-3'-fluoroacetophenone afforded the alcoholic product, which is a key synthetic intermediate of the medicine crizotinib, in 98\% ee.

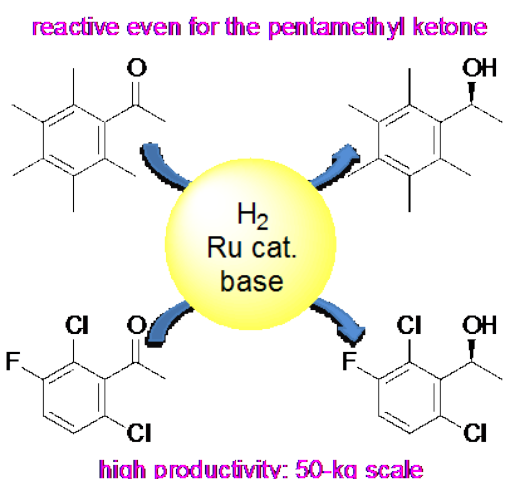

Noriyuki Utsumi, Noriyoshi Arai, Kei Kawaguchi, Takeaki Katayama,

Toshihisa Yasuda, Kunihiko Murata, and Takeshi Ohkuma*

Page No. - Page No.

Asymmetric Hydrogenation of Polysubstituted Aromatic Ketones Catalyzed by the DIPSkewphos/PICA Derivative-Ruthenium(II) Complexes 